\title{
Study of Several Important Immune Markers in Hepatitis B patients
}

Received : 7/12/2017

\section{Accepted : 18/1/2018}

\author{
Ehsan F. Hussein \\ University of Sumer/College of Basic Education; Iraq \\ E mail: ehsan.algrani@yahoo.com
}

\begin{abstract}
$\underline{\text { Abstract: }}$
Hepatitis B patients have been collected from Marjan Teaching Hospital in Babylon Province through the period from May/2017 to September/2017. Were for study of several immune markers in serum isolated from these patients. The immune markers were involved of the antibody types as well as Rheumatoid factor and CReactive protein. The antibodies were involved $\operatorname{IgA}$, IgM and IgG. The results were showed significant elevation in concentration of the $\operatorname{IgG}$ antibody and also elevation in concentrations of the $\operatorname{IgM}$ and $\operatorname{IgA}$ antibodies but no significant when comparison of these antibodies with apparently healthy persons antibodies concentrations. Also this study was explained increases in presence percentages of both the Rheumatoid factor and C-Reactive protein in serum of these patients in comparison with same apparently healthy persons that have no presence percentages for both Rheumatoid factor and C-Reactive protein.
\end{abstract}

Key words: Hepatitis B Patients, Antibodies, Rheumatoid Factor, C-Reactive Protein.

\section{Introduction:}

The Virus of Hepatitis B is a type of the noncytopathogenic, hepato-pathogenic of the Hepadnaviridae family, that causes variable degrees of the humans liver diseases [1]. This virus can causes either chronic or acute infections, the infections in adult have relatively low chronicity rate about $5 \%$ and infections of neonatal mostly have high rate of persistence [2]. Chronic infections are usually asymptomatic, but carriers of this virus can be developing life threatening infections like cirrhosis and hepatic carcinoma [3]. Despite the availability of the prophylactic vaccines, hepatitis B virus is estimated to infect around 400 million peoples worldwide, with endemic areas in Africa and Asia [1]. And the range of the infections in different countries from $(0.1 \%$ to $20 \%$ ) [4].

The response of the antibodies to the antigens of the enveloped viruses (like, HBV) play the specific roles in the removing of the these viruses from the bloodstream of infected patients, and this acting for decreasing the releasing of the viruses within the host, as well as in the protection against perinatal viral infections [5]. Titers detection of the total anti 
Hepatitis B viruses in the serum mostly used as standard to response of the immunity against surfaces antigens of the hepatitis B virus [6]. Several studies have certain that the humoral immunity through neutralize antibodies response is more effective against many viral protein antigens [7].

The antibodies response to the virus of the Hepatitis B infections is difficult to experimentally study [8]. Free antibodies to the surface antigens is not detected until after the resolution of this virus infections [9]. The present of the antibodies associated with Hepatitis B viral infection in immune complexes in the circulating in both infections of the acute and chronic types, proposing that production of the antibodies are much speedily than identified and that they plays specific roles in the pathological disease [10]. The specific antibodies against the hepatitis $\mathrm{B}$ virus antigens have properties of neutralizing and mediate protective immune response [11].

The Rheumatoid factor; RF is a class of the antibodies that have several affinities and isotypes, were first reveal before more than seventy years ago, but there is yet much to discover about the mechanisms implied their production, pathological effects and physiological roles [12]. This autoantibody found directed against the Fc portion of the antibody (IgG) [13].

This factors have been reported that their appearance in the serum is sequential before diagnosis; first $\operatorname{IgM} \mathrm{RF}$, then $\operatorname{IgA} \mathrm{RF}$ and finally $\operatorname{IgG}$ RF [14]. It is found in the patients serum with diseases types, including autoimmune and nonautoimmune conditions [15]. And this factor associated with hepatitis B virus infections [16].

The C-reactive protein; CRP firstly identified and explained in 1930 by the Tillet and Francis and routinely considered an important immune regulator of the innate immunity [17]. They are the acute phase proteins, nonspecific industries by the liver in responses to the inflammations of the acute and chronic infections [18].

The production of the C-reactive protein is regulated through the cytokines of the proinflammatory type [19]. The studies demonstrated the production of this protein in correlates with progression diseases in chronic hepatitis B infections [20].

\section{Materials and Methods:}

\section{The Patients and Samples}

The study cases were males and female of patients infected with Hepatitis B virus, they collected from Marjan Teaching Hospital in Babylon Province, the samples were serum taken from these patients and used for the study of the several immune markers concentration, the immune markers were $\operatorname{Ig} \mathrm{A}, \operatorname{IgM}, \operatorname{IgG}, \mathrm{RF}$ and CRP. 
Identification of the Patients by (HBsAg EIA Test Kit Package Insert): according to the (ACON Laboratories Inc. San Diego; USA)

The Patients were identified in hospital as Hepatitis-B-Patients according to (Foresight) an enzyme immunoassay (EIA) for the qualitative detection of the hepatitis B surface Antigen (HBsAg) in the human serum: this for the professional diagnosis use only [21].

Determination of the antibodies (IgA, IgM and IgG) by the Redial

\section{Immunodiffusion.}

This according to (Roseto degli Abruzzi (Te) Italy, LIOFILCHEM(R) s.r.i.) was include:

1. Removed EASY RID from the envelope, open the plate and leave about $(5 \mathrm{~min})$ at room temperature so that any condensed water in the well can evaporate.

2. Filled the wells with the $(5 \mu \mathrm{l})$ of undiluted patients samples (serums).

3. Closed the plate with the lid, after the sample have been diffusion into the gel, leave to stand, overturned into the envelope at room temperature for ( $48 \mathrm{~h}$ ).

4. Measured the diameters of the precipitin rings using suitable devices.

5. Determined the concentrations of the antibodies were by comparison of the formed rings with the attachment tables of the same company.

\section{Determination of the (Rheumatoid factor and C-Reactive protein)}

\section{Rheumatoid factor: RF-Latex.}

This according to (SPINRECT,S.A Ctra.Santa Colma, 7E-17176 SANT) (ESTEVE DE BAS (GI) SPAIN).

\section{C-Reactive protein: CRP-Latex.}

This according to (LINER CHEMICALS S.L. Joaquim Costa $182^{\text {a }}$ planta. 08390 Montgat, Barcelona, SPAIN).

And determination of both the RF-Latex and CRP-Latex by Qualitative method (slide agglutination test) was include:

1. Left of the kit components and samples at room temperature, if the sensitive of this test decrease at low temperatures.

2. Placed a drop of sample on the custom circle in strip test.

3. Placed a drop of (RF or CRP) Latex reagent gently and next to the specimen drop.

4. Mixed well and then spread along the inner surface of the circuit in the test strip.

5. Slide the slide tilted forward and backward and continue for two minutes, with the positive result appearing in a agglutination manner. 


\section{Statistical analysis}

The results were analyzed by the Statistical Package Social Sciences (SPSS) [22], version 20 this for determination of the Mean, Medium, Standard deviation and Standard error, as well as the significant presence between antibodies have been calculated according to One Way ANOVA by descriptive excluded cases analysis by analysis with LSD at (95\%) confidence and level of significant $(\mathrm{P}=0.05)$.

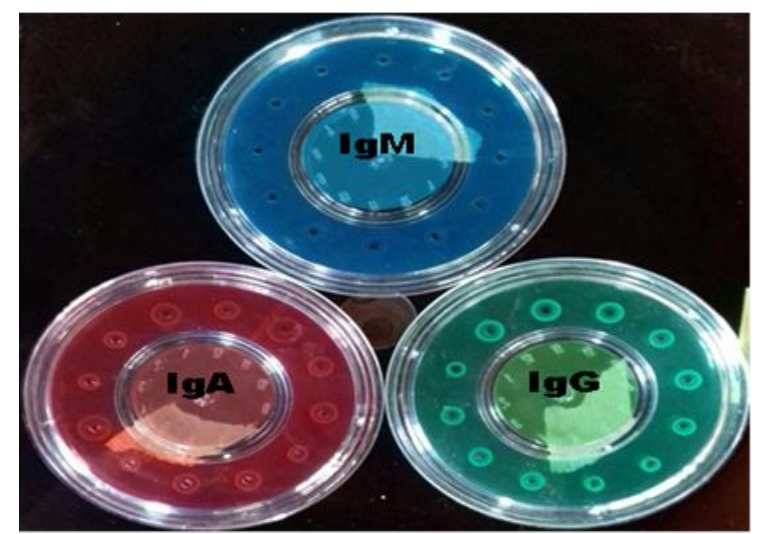

Figuer:1. Zones were formed in the antibodies (IgM), (IgA) and (IgG) kits after two days from placed hepatitis-Bpatients serum.

Figure (1) the zone were formed by reaction between the $\operatorname{Ig} \mathrm{A}, \operatorname{IgM}$ and $\operatorname{IgG}$ antibodies kits with hepatitis-B-patients serum after (48 h) from placed the patients serum in the kits wells of these antibodies.

\section{$\underline{\text { Results: }}$}

The results explained elevation in concentrations of the antibodies (IgA, IgM and $\mathrm{IgG})$ as well as presence percentage of the Rheumatoid factor and C-Reactive protein of the patients when comparison with apparently healthy persons and these illustrated in following tables and figures.

\section{Table:1. Concentrations of the antibodies} types in apparently healthy persons.

\begin{tabular}{|c|c|c|c|c|}
\hline $\begin{array}{l}\text { Study } \\
\text { groups }\end{array}$ & $\begin{array}{l}\text { Statistical } \\
\text { analysis }\end{array}$ & $\begin{array}{c}\text { IgA } \\
(\mathrm{Mg} / \mathrm{dL})\end{array}$ & $\begin{array}{c}\text { IgM } \\
(\mathrm{Mg} / \mathrm{dL})\end{array}$ & $\begin{array}{c}\text { IgG } \\
(\mathrm{Mg} / \mathrm{dL})\end{array}$ \\
\hline & Mean & 162 & 98.983 & 1184.834 \\
\hline $\begin{array}{c}\text { apparently } \\
\text { healthy }\end{array}$ & $\begin{array}{l}\text { Standard } \\
\text { Deviation }\end{array}$ & 45.786 & 55.009 & 388.845 \\
\hline & $\begin{array}{c}\text { Standard } \\
\text { Error }\end{array}$ & 13.218 & 15.879 & 112.249 \\
\hline & Mean & 164.167 & 111.001 & 1214.334 \\
\hline apales & $\begin{array}{l}\text { Standard } \\
\text { Deviation }\end{array}$ & 54.441 & 68.354 & 460.649 \\
\hline persons & $\begin{array}{c}\text { Standard } \\
\text { Error }\end{array}$ & 22.226 & 27.905 & 188.059 \\
\hline \multirow{3}{*}{\begin{tabular}{|c|} 
Females \\
apparently \\
healthy \\
persons
\end{tabular}} & Mean & 160.034 & 86.967 & 1155.334 \\
\hline & $\begin{array}{l}\text { Standard } \\
\text { Deviation }\end{array}$ & 40.471 & 40.474 & 344.027 \\
\hline & $\begin{array}{c}\text { Standard } \\
\text { Error }\end{array}$ & 16.522 & 16.524 & 140.449 \\
\hline \multirow{3}{*}{\multicolumn{2}{|c|}{$\begin{array}{c}* \text { References } \\
\text { normal Igs } \\
\text { concentrations }\end{array}$}} & $\operatorname{IgA}$ & \multicolumn{2}{|c|}{$90-490(\mathrm{Mg} / \mathrm{dL})$} \\
\hline & & IgM & \multicolumn{2}{|c|}{$50-370(\mathrm{Mg} / \mathrm{dL})$} \\
\hline & & IgG & \multicolumn{2}{|c|}{$800-1800(\mathrm{Mg} / \mathrm{dL})$} \\
\hline
\end{tabular}

Table (1) means of the $\operatorname{IgA}$ in all apparently healthy persons, males apparently healthy persons and females apparently healthy persons were $162.101 \mathrm{Mg} / \mathrm{dL}, 164.167 \mathrm{Mg} / \mathrm{dL}$ and $160.034 \mathrm{Mg} / \mathrm{dL}$ respectively; while for IgM were $98.983 \mathrm{Mg} / \mathrm{dL}, 111.001 \mathrm{Mg} / \mathrm{dL}$ and $86.967 \mathrm{Mg} / \mathrm{dL}$ respectively; and for $\mathrm{IgG}$ were $1184.834 \mathrm{Mg} / \mathrm{dL}, 1214.334 \mathrm{Mg} / \mathrm{dL}$ and $\mathrm{Mg} / \mathrm{dL} 1155.334$ respectively. 
Table:2. Concentrations of the antibodies types in Hepatitis B Patients.

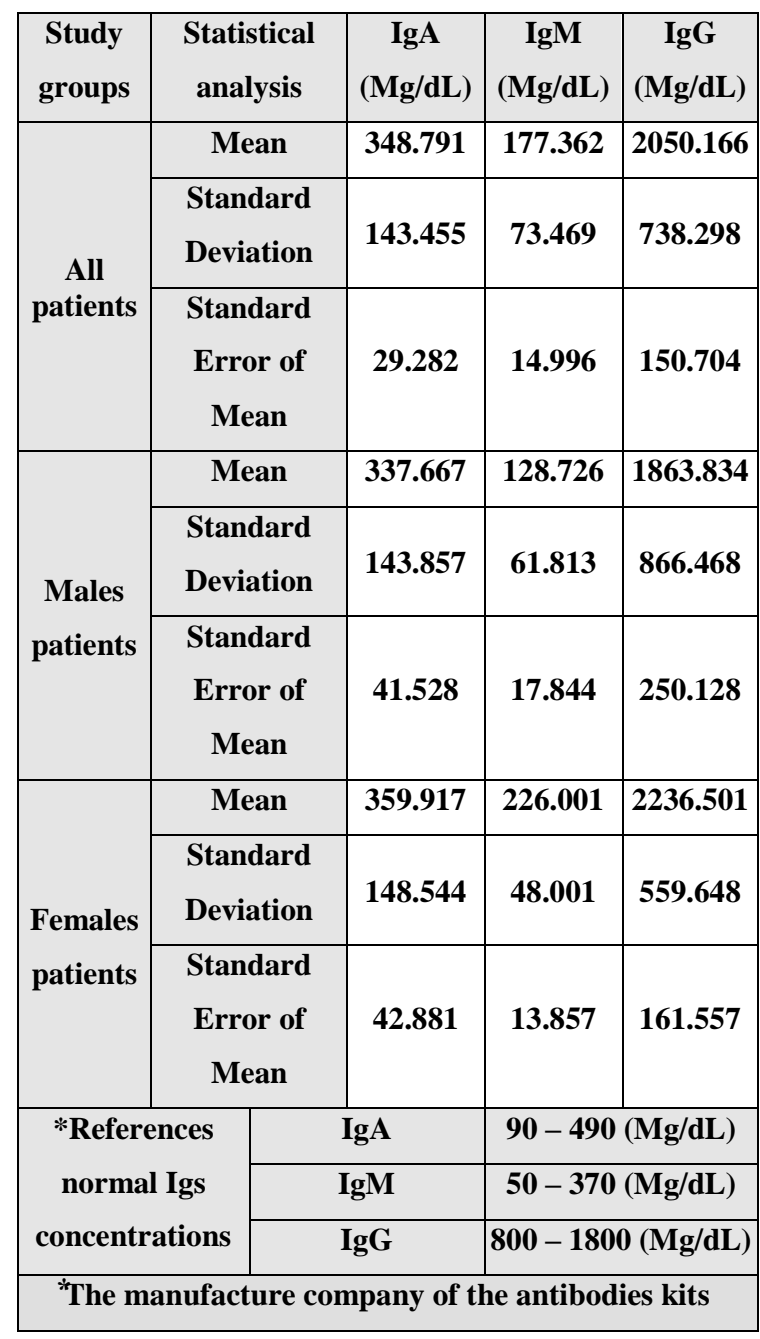

Table (2) means of the IgA in all Hepatitis-BPatients, males Hepatitis-B-Patients and females hepatitis-B-patients were 348.791 $\mathrm{Mg} / \mathrm{dL}, 337.667 \mathrm{Mg} / \mathrm{dL}$ and $359.917 \mathrm{Mg} / \mathrm{dL}$ respectively; whereas the IgM were 177.362 $\mathrm{Mg} / \mathrm{dL}, 128.726 \mathrm{Mg} / \mathrm{dL}$ and $226.001 \mathrm{Mg} / \mathrm{dL}$ respectively; and the IgG were 2050.166 $\mathrm{Mg} / \mathrm{dL}, 2236.501 \mathrm{Mg} / \mathrm{dL}$ and $\mathrm{Mg} / \mathrm{dL} 1155.334$ respectively.
Table:3. Significant differences between of the study groups according to LSD system.

\begin{tabular}{|c|c|c|c|}
\hline \begin{tabular}{|c|} 
Comparison between of the \\
antibodies types of the \\
study groups in $(\mathrm{Mg} / \mathrm{dL})$
\end{tabular} & $\begin{array}{c}\text { Mean } \\
\text { Difference }\end{array}$ & $\begin{array}{l}\text { Stand. } \\
\text { Error }\end{array}$ & Sig. \\
\hline \begin{tabular}{|l|} 
The IgA of the patients and \\
apparently healthy persons
\end{tabular} & 186.692 & 134.921 & 0.169 \\
\hline $\begin{array}{l}\text { The IgM of the patients } \\
\text { and apparently healthy } \\
\text { persons }\end{array}$ & 78.379 & 134.921 & 0.563 \\
\hline $\begin{array}{l}\text { The IgG of the patients and } \\
\text { apparently healthy }\end{array}$ & $865.333^{*}$ & 134.921 & 0.001 \\
\hline $\begin{array}{|llr|}\text { The IgA of the } & \text { male } \\
\text { patients } & \text { and } & \text { male } \\
\text { apparently healthy persons }\end{array}$ & 173.501 & 223.925 & 0.442 \\
\hline $\begin{array}{|lll|}\text { The IgM of the } & \text { male } \\
\text { patients and } & \text { male } \\
\text { apparently healthy } & \end{array}$ & 17.726 & 223.925 & 0.937 \\
\hline $\begin{array}{|lll|}\text { The IgG of the } & \text { male } \\
\text { patients } & \text { and } & \text { male } \\
\text { apparently healthy persons }\end{array}$ & $649.501 *$ & 223.925 & 0.006 \\
\hline \begin{tabular}{|lll} 
The IgA of the female \\
patients and & female \\
apparently healthy persons
\end{tabular} & 199.884 & 150.026 & 0.189 \\
\hline $\begin{array}{l}\text { The IgM of the female } \\
\text { patients and female } \\
\text { apparently healthy persons }\end{array}$ & 139.034 & 150.026 & 0.359 \\
\hline \begin{tabular}{|lll} 
The IgG of the female \\
patients and & female \\
apparently healthy persons
\end{tabular} & $1081.167 *$ & 150.026 & 0.001 \\
\hline \multicolumn{4}{|c|}{ "The mean difference is significant at the 0.05 leve } \\
\hline
\end{tabular}

Table (3) significant differences between all, males and females patients were 0.001, 0.006 and 0.001 respectively of the $\operatorname{IgG}$ when comparison with same groups of the apparently healthy persons. And no significant differences were presented of both IgA and IgM for all study groups. 
Table:4. Age categories and number of the study groups.

\begin{tabular}{|c|c|c|c|c|c|c|}
\hline \multirow{2}{*}{$\begin{array}{c}\text { Age } \\
\text { categories }\end{array}$} & \multicolumn{3}{|c|}{ Number of } & \multicolumn{3}{c|}{ Number of } \\
\cline { 2 - 7 } & $\begin{array}{c}\text { Hepatitis } \\
\text { Patients }\end{array}$ & $\begin{array}{c}\text { Male } \\
\text { patients }\end{array}$ & $\begin{array}{c}\text { Female } \\
\text { patients }\end{array}$ & $\begin{array}{c}\text { Mpparently } \\
\text { healthy } \\
\text { persons }\end{array}$ & $\begin{array}{c}\text { Female } \\
\text { hearently } \\
\text { healthy } \\
\text { persons }\end{array}$ & $\begin{array}{c}\text { apparently } \\
\text { healthy } \\
\text { persons }\end{array}$ \\
\hline $25-30$ & 10 & 4 & 6 & 4 & 2 & 2 \\
\hline $31-36$ & 14 & 6 & 8 & 6 & 2 & 4 \\
\hline $37-42$ & 10 & 6 & 4 & 4 & 2 & 2 \\
\hline $43-48$ & 6 & 4 & 2 & 6 & 4 & 2 \\
\hline $49-54$ & 8 & 4 & 4 & 4 & 2 & 2 \\
\hline Total & 48 & 24 & 24 & 24 & 12 & 12 \\
\hline
\end{tabular}

Table (4) number of the patients and persons as well as number of the males and females within these groups, these placed in five categories of the ages, this used for drown histograms between antibodies means for these age categories and comparison between these study groups as in figures numbered from (figure:2. to figuer:10).

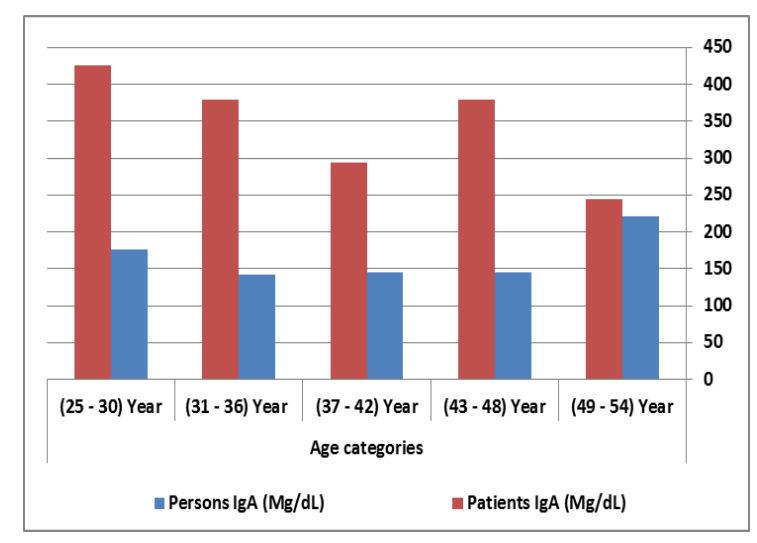

Figuer:2. Comparison between the concentration of the $(\operatorname{IgA})$ in age categories of the patients and apparently healthy persons.

Figure (2) elevation in the (IgA) antibody concentration of the patients in comparison with persons.

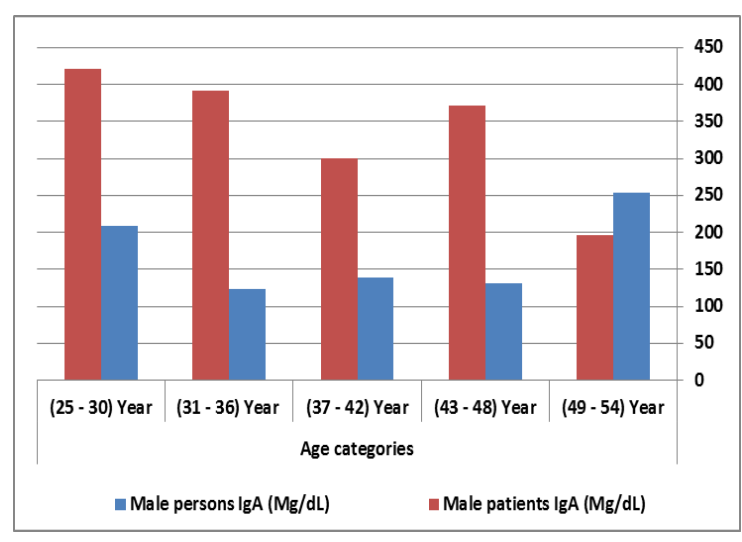

Figuer:3. Comparison between the concentration of the (IgA) in age categories of the male patients and male apparently healthy persons.

Figure (3) raising in the ( $\operatorname{Ig} \mathrm{A})$ antibody concentration of the males patients in comparison with males persons except (49-54) age category.

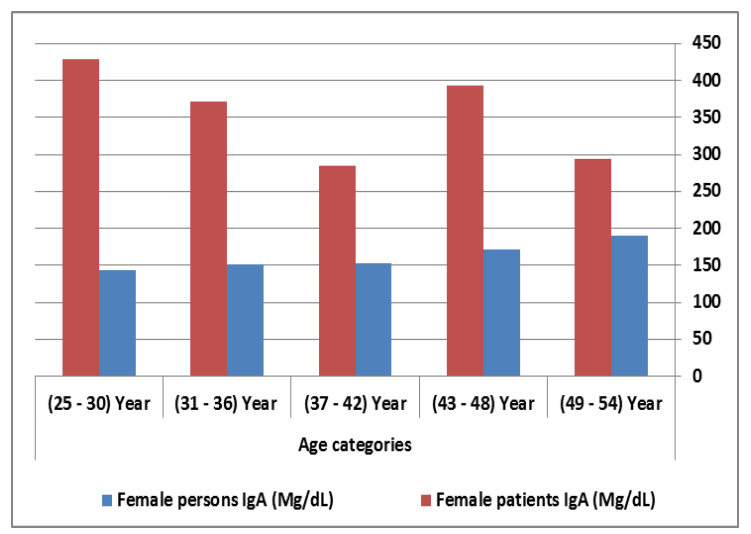

Figuer:4. Comparison between the concentration of the (IgA) in age categories of the female patients and female apparently healthy persons.

Figure (4) increasing in ( $\operatorname{Ig} \mathrm{A})$ antibody concentration of the females patients in comparison with females persons. 


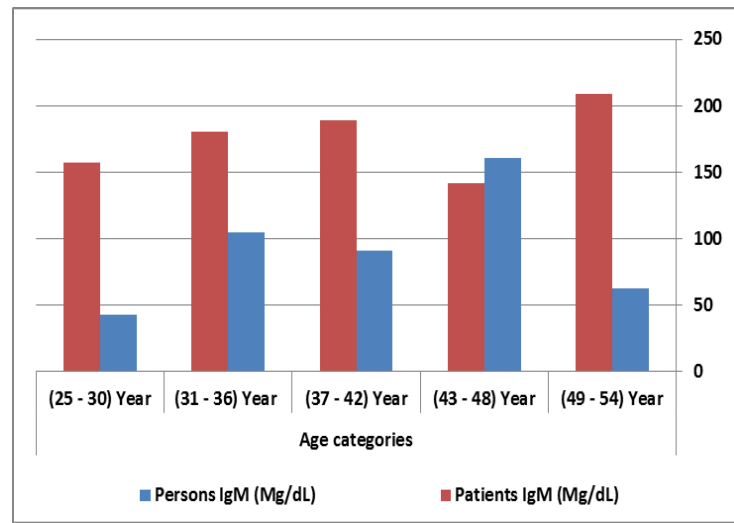

Figuer:5. Comparison between the concentration of the (IgM) in age categories of the patients and apparently healthy persons.

Figure (5) raising in the (IgM) antibody concentration of the patients in comparison with persons except (43-48) age category.

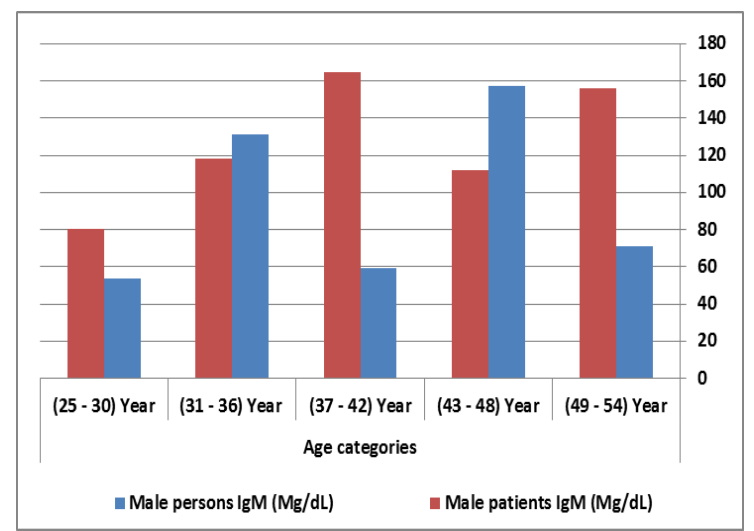

Figuer:6. Comparison between the concentration of the (IgM) in age categories of the male patients and male apparently healthy persons.

Figure (6) elevation in the (IgM) concentration of the males patients in comparison with males persons except (31-36) \& (34-48) age categories.

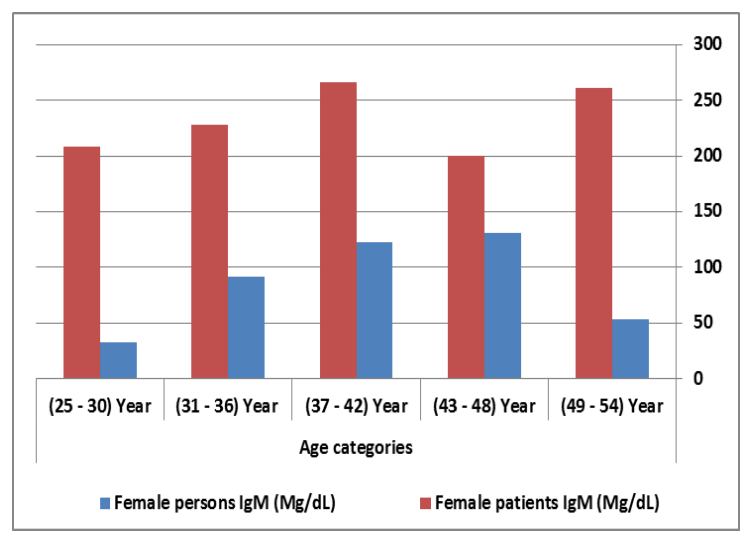

Figuer:7. Comparison between the concentration of the (IgM) in age categories of the female patients and female apparently healthy persons.

Figure (7) increasing in the (IgM) antibody concentration of the females patients in comparison with females persons.

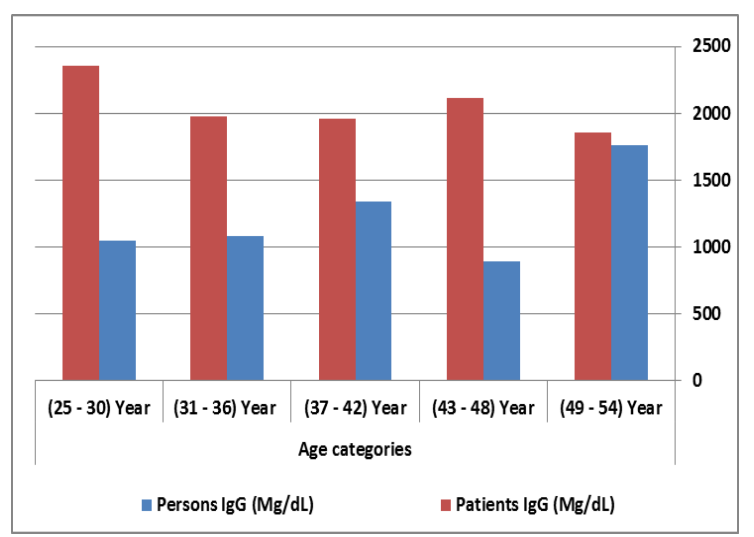

Figuer:8. Comparison between the concentration of the (IgG) in age categories of the patients and apparently healthy persons.

Figure (8) raising in the ( $\operatorname{IgG}$ ) antibody concentration of the patients in comparison with persons. 


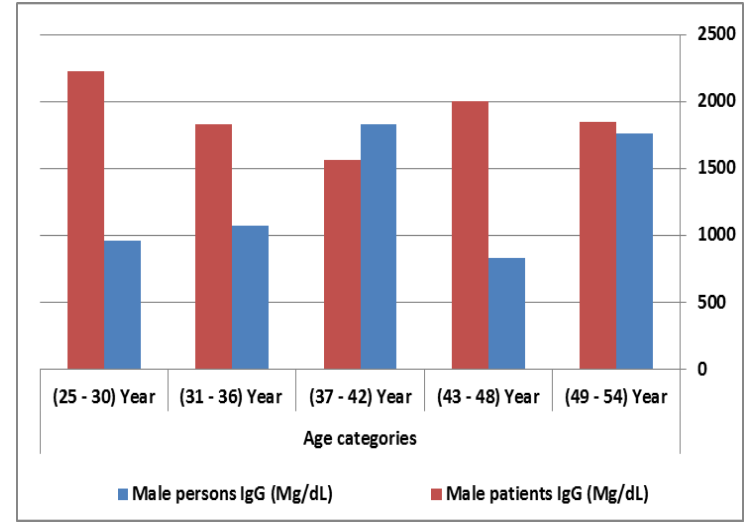

Figuer:9. Comparison between the concentration of the (IgG) in age categories of the male patients and male apparently healthy persons.

Figure (9) elevation in the ( $\operatorname{IgG}$ ) antibody concentration of the males patients in comparison with males persons except (37-42) age category.

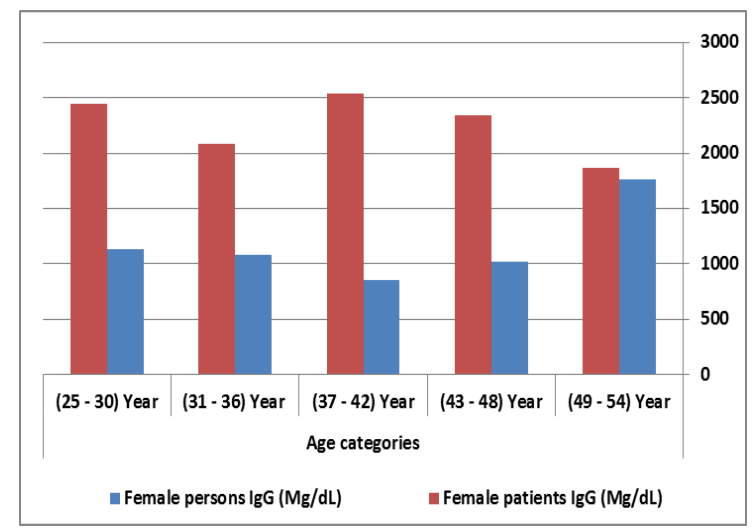

Figuer:10. Comparison between concentration of the (IgG) in age categories of the female patients and female apparently healthy persons.

Figure (10) increasing in the (IgG) antibody concentration of the females patients in comparison with females persons.
Table:5. Percent of the Rheumatoid factor (RF) and C-Reactive protein (CRP) in the patients and persons.

\begin{tabular}{|c|c|c|c|c|c|}
\hline \multirow{2}{*}{ Result } & \multicolumn{2}{|c|}{ Persons } & \multicolumn{2}{c|}{ Patients } \\
\cline { 2 - 6 } All & $\begin{array}{c}\text { Positive } \\
\text { percent (\%) }\end{array}$ & $0 \%$ & $\mathbf{0} \%$ & $\mathbf{8 . 3 3 3} \%$ & $\mathbf{2 5} \%$ \\
\cline { 2 - 6 } & $\begin{array}{c}\text { Negative } \\
\text { percent (\%) }\end{array}$ & $\mathbf{1 0 0} \%$ & $\mathbf{1 0 0} \%$ & $\mathbf{9 1 . 6 6 6} \%$ & $\mathbf{7 5} \%$ \\
\hline \multirow{2}{*}{ Male } & $\begin{array}{c}\text { Positive } \\
\text { percent (\%) }\end{array}$ & $\mathbf{0} \%$ & $\mathbf{0} \%$ & $\mathbf{1 6 . 6 6 6} \%$ & $\mathbf{5 0} \%$ \\
\cline { 2 - 6 } & $\begin{array}{c}\text { Negative } \\
\text { percent (\%) }\end{array}$ & $\mathbf{1 0 0} \%$ & $\mathbf{1 0 0} \%$ & $\mathbf{8 3 . 3 3 3} \%$ & $\mathbf{5 0} \%$ \\
\hline \multirow{2}{*}{ Female } & $\begin{array}{c}\text { Positive } \\
\text { percent (\%) }\end{array}$ & $\mathbf{0} \%$ & $\mathbf{0} \%$ & $\mathbf{0} \%$ & $\mathbf{0} \%$ \\
\cline { 2 - 6 } & $\begin{array}{c}\text { Negative } \\
\text { percent (\%) }\end{array}$ & $\mathbf{1 0 0} \%$ & $\mathbf{1 0 0} \%$ & $\mathbf{1 0 0} \%$ & $\mathbf{1 0 0} \%$ \\
\hline
\end{tabular}

Table (5) all of the patients have positive percent of the (RF) and (CRP) were (8.333\%) and (25\%) respectively; while the males patients have positive percent were $(16.666 \%)$ and (50\%) for (RF) and (CRP) respectively; and the females patients have positive percent were $(0 \%)$ for both (RF) and (CRP), whereas the apparently healthy persons have positive percent of both the (RF) and (CRP) were (0\%).

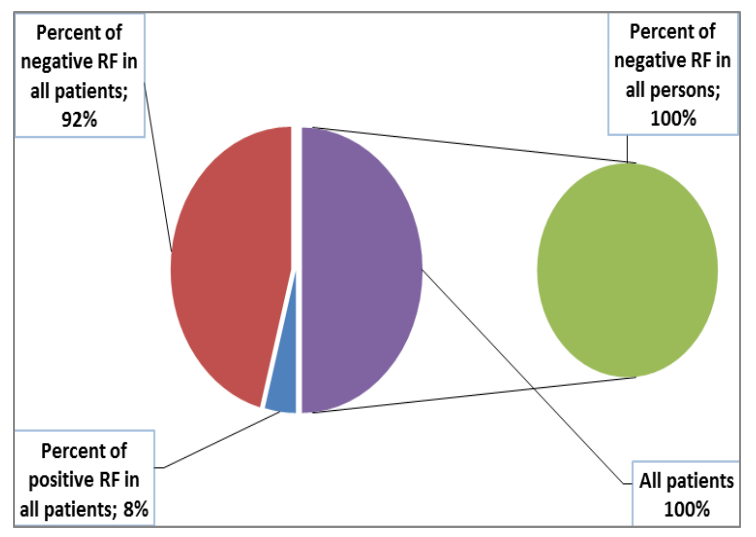

Figuer:11. Comparison between the percent of the Rheumatoid factor (RF) in patients and apparently healthy persons.

Figure (11) percent of the positive (RF) in patients was (8\%), whereas the negative in patients and persons were (92\%) and (100\%) respectively. 


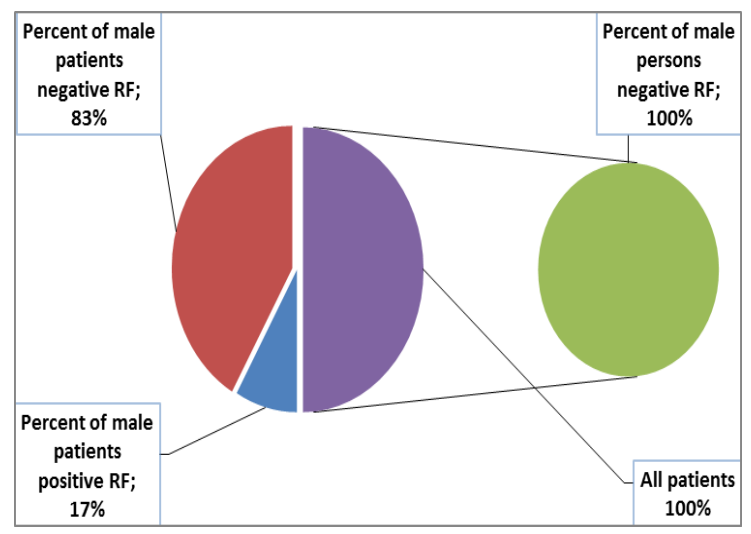

Figuer:12. Comparison between the percent of the Rheumatoid factor (RF) in male patients and male apparently healthy persons.

Figure (12) percent of the positive (RF) in males patients was (17\%), while the negative in males patients and females persons were (83\%) and $(100 \%)$ respectively.

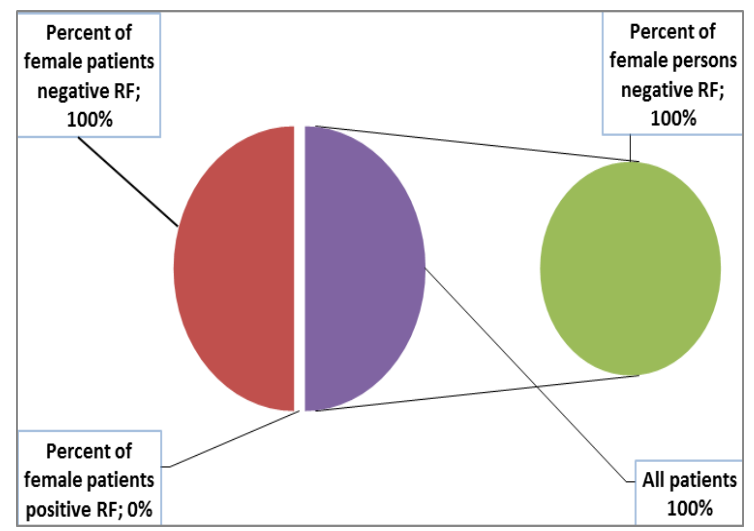

Figuer:13. Comparison between the percent of the Rheumatoid factor (RF) in female patients and female apparently healthy persons.

Figure (13) percent of the positive (RF) in females patients was (0\%), whereas the negative in females patients and females persons were (100\%) and (100\%) respectively.

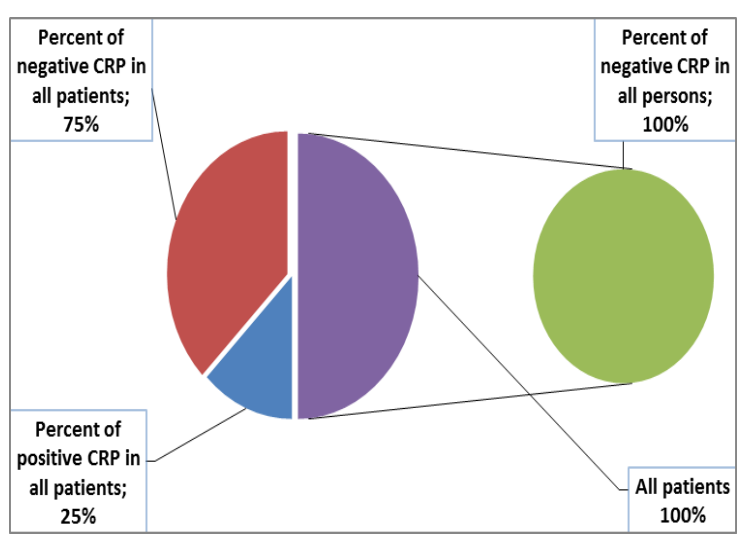

Figuer:14. Comparison between the percent of the C-Reactive Protein (CRP) in patients and apparently healthy persons.

Figure (14) percent of the positive (CRP) in patients was $(25 \%)$, while the negative in patients and persons were (75\%) and (100\%) respectively.

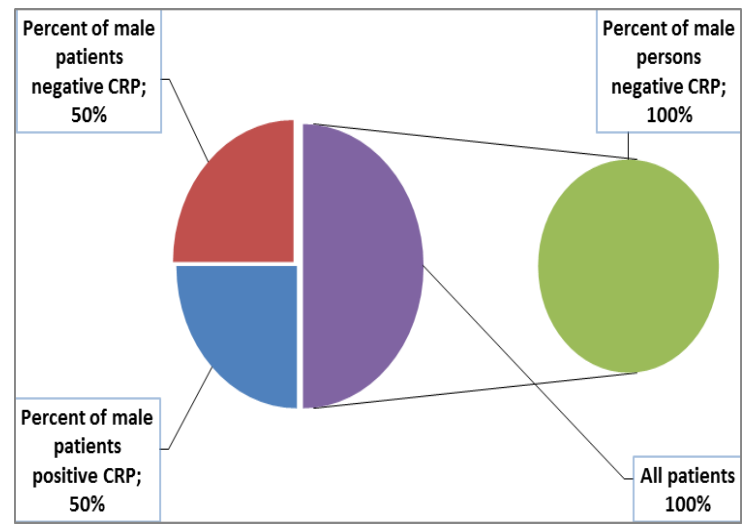

Figuer:15. Comparison between the percent of the C-Reactive Protein (CRP) in male patients and male apparently healthy persons.

Figure (15) percent of the positive (CRP) in males patients was (50\%), whereas the negative in males patients and males persons were (50\%) and $(100 \%)$ respectively. 


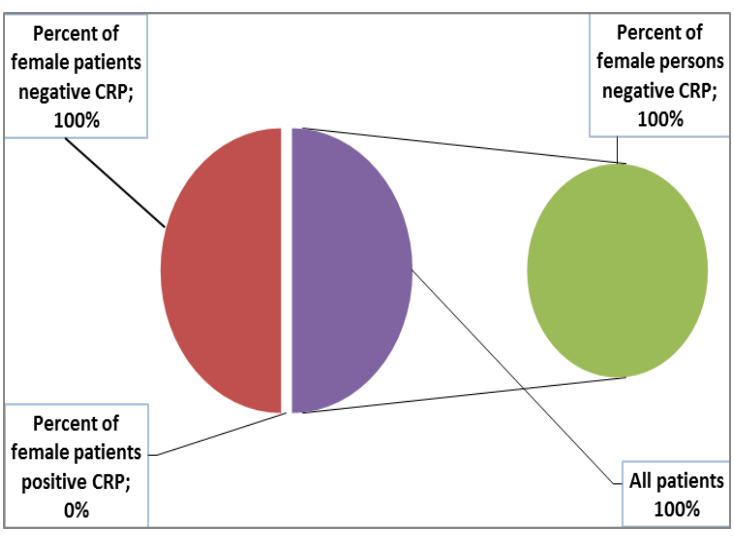

Figuer:16. Comparison between the percent of the C-Reactive Protein (CRP) in female patients and female apparently healthy persons.

Figure (16) percent of the positive (CRP) in females patients was $(0 \%)$, while the negative in females patients and females persons were $(100 \%)$ and $(100 \%)$ respectively.

\section{Discussion:}

Table (2 and 3) explained the significant elevation in the concentration of the antibody (IgG) as well as no significant elevation in the concentrations of the both antibodies ( $\operatorname{IgM})$ and (IgA) of the patients when comparison the concentration of these antibodies with same antibodies of the apparently healthy persons table (1 and 3). And when comparison the present results with other workers, Stoica et al who found the $\operatorname{IgM}$ was remarkably higher while the $\operatorname{IgG}$ and $\operatorname{IgA}$ were significantly greater in patients than in controls [23]. Bersohn et al explaind the IgM level was significantly higher while the levels of the $\operatorname{Ig} \mathrm{A}$ and $\mathrm{IgG}$ were not significantly different in the
hepatitis-B infected patients [24]. Joshi et al illustrated the All antibodies IgA, IgM and IgG were elevated significantly in HBV infections [25].

The responses of the adaptive immunity consist from the complexes of the network of the effector immune cell types, all of these plays a specific role in the elevation of the immunity against of the hepatitis $B$ virus infections, the CD4 T-cell, named as the helper $\mathrm{T}$-cell, are active for cytokines production and are important in the activation of the effector cytotoxic CD8 T-cell and antibody production B-cell type [26]. The CD8 T-cell pass on to clear of hepatitis B virus infected hepatocytes through the mechanisms of noncytolytic and cytolytic, also decreasing of the level of this virus [27].

The dendritic cells act as represent cells that production of the specialized antigens for necessary cells populations acting with elevation response of adaptive immune system [28]. With regard to their important role in $\mathrm{T}$ cell suppository, efficiently and working changes of the dendritic cells can explain the case of the lower responses within B-cell and Tcell in patients with chronic hepatitis B [26]. The B-cell can remove and prevent viral infections and/or reinfection through production of the antibodies [29].

Table (5) explained the positive percent of the rheumatoid factor (RF) in hepatitis $B$ patients was $(8.333 \%)$. As well as the results of the males and females patients and control were 
illuminated in figures (11 to 13). And when comparison these results with other workers, Arai et al who found this factor was positive in (39.5\%) of the all hepatitis B patients [30]. Dalkilic et al who found RF factor was positive in $(18.7 \%)$ of the all HBV patients [31]. Choi et $a l$ who found RF factor was positive in $(3.5 \%)$ of the all hepatitis B patients [16].

The patients that infected with hepatitis B virus explain elevation in the positivity rates of rheumatoid factor [32]. A chronic infections including hepatitis B produce high levels of this factor [33]. Recent studies demonstrated the HBV infections can increasing of specific Bcells activation [34]. In hepatitis B infections the $\mathrm{HBeAg}$-antibody complex may play role in rheumatoid factor formation [32]. And production of this factor can by antigen specific $\mathrm{B}$ cells with help from $\mathrm{T}$ cells as a resulting of binding and processing of immune complexes in which IgG functions as antigen [35]. Another mechanism of RF production including cross reactivity between epitopes of antigen and/or auto antigen with antibody-G, as well as the polyclonal $\mathrm{B}$ cell activation during infections and responses can be another cause of rheumatoid factor formation [36].

Table (5) showed the positive percent of the C-reactive protein (CRP) in hepatitis B patients was $(11.68 \%)$. As well as the results of the males and females patients and control were illustrated in figures (14 to 16). Ma et al who found this factor was positive in $(3.5 \%)$ of the all Hepatitis B patients [37]. Liu who found this factor was positive in (37.97\%) of the all Hepatitis B patients with liver cirrhosis patients [38].

The protein of C-reactive is the reactant of acute phase associated with the tissue damage and liver inflammation [39]. This protein strongly associated with the chronic infections of the hepatitis B viruses and can reflect the severity of liver damage [40]. liver inflammations in patients infected with HBV have been confirmed to be mediated by the cytokines that may plays a specific roles in the pathogenesis of chronic infection with this virus [41]. This protein is manufactured in the acute phase of the inflammations in responses to interleukin-6 (IL-6) and an elevated in this protein suggests the presence of hepatic inflammation as a result of liver injury [42]. This protein is up regulated by cytokines such as interleukin-6 (IL6) and tumor necrosis factor (TNF) [43].

\section{Conclusions:}

The IgG antibody elevation associated with hepatitis B virus infections as well as, increase in the concentrations of the Rheumatoid Factor and C-Reactive can be found in this disease. And these immune markers can be used for identification and explanation the progress of hepatitis B infections and diseases. 


\section{References:}

1. Busca, A. and Kumar, A. (2014). Innate immune responses in hepatitis B virus (HBV) infection. Virol J. 11: 22.

2. McMahon, B.J. (2010). Natural history of chronic hepatitis B. Clin Liver Dis. 14(3): 381-396.

3. Yuen, M.F. and Lai, C.L. (2001). Treatment of chronic hepatitis B. Lancet Infect Dis. 1(4): 232-241.

4. Shi, Z.; Yang, Y.; Ma, L. and Li, X (2010). Schreiber A. Lamivudine in late pregnancy to interrupt in utero transmission of hepatitis B virus: a systematic review and meta-analysis. Obstet Gynecol. 116:147-159.

5. Zinkernagel, R.M. and Hengartner, H. (1997). Antiviral immunity. Immunol Today. 18: 258-60.

6. Gregorek, H.; Madalinski, K.; Woynarowski, M.; Mikolajewicz, J.; Syczewska, M. and Socha, J. (2000). IgG Subclass Distribution of Hepatitis B Surface Antigen Antibodies Induced in Children with Chronic Hepatitis B Infection after Interferon- $\alpha$ Therapy. The Journal of Infectious Diseases. 181(6): 2059-2062.
7. Robbins, J.B.; Schneerson, R. and Szu, S.C. (1995). Perspective: hypothesis: serum $\operatorname{IgG}$ antibody is sufficient to confer protection against infectious diseases by inactivating inoculum, J Infect Dis. 17: 1387-98.

8. Ciupe, S.M.; Ribeiro, R.M. and Perelson, A.S. (2014). Antibody Responses during Hepatitis B Viral Infection. PLOS Computational Biology. 10(7): 1-16.

9. Lai, C. and Locarnini, S. (2002). Hepatitis B virus. London, UK: International Medical Press.

10. Rath, S. and Devey, M. (1988). IgG subclass composition of antibodies to HBsAg in circulating immune complexes from patients with hepatitis B virus infections. Clin Exp Immunol. 72: 164-167.

11. Glebe, D.; Lorenz, H.; Gerlich, W.; Butler, S. and Tochkov, I. (2009). Correlation of virus and host response markers with circulating immune complexes during acute and chronic woodchuck hepatitis virus infection. $J$ Virol. 83: 1579-1591.

12. Dorner, T.; Egerer, K.; Feist, E. and Burmester, G.R. (2004). Rheumatoid 
factor revisited. Current Opinion in Rheumatology. 16(3): 246-253.

13. Falkenburg, W.J.J.; Schaardenburg, D.V.; Heer, P.O.; Wolbink, G. and Rispens, T. (2015). IgG Subclass Specificity Discriminates Restricted IgM Rheumatoid Factor Responses From More Mature Anti-Citrullinated Protein Antibody-Associated or Isotype-Switched IgA Responses. Arthritis \& Rheumatology. 67(12): 3124-3134.

14. Deane, K.D.; Norris, J.M. and Holers, V.M. (2010). Preclinical rheumatoid arthritis: identification, evaluation, and future directions for investigation. Rheumatic Disease Clinics of North America. 36(2): 213241.

15. Ingegnoli, F.; Castelli, R. and Gualtierotti, R. (2013). Rheumatoid Factors: Clinical Applications. Dis Markers. 35(6): 727-734.

16. Choi, S.T.; Lee, H.W.; Song, J.S.; Lee, S.K. and Park, Y.B. (2014). Analysis of rheumatoid factor according to various hepatitis B virus infectious statuses. Clin Exp Rheumatol. 32(2):168-173.
17. Ridker, P.M. (2009). C-Reactive protein: eighty years from discovery to emergence as a major risk marker for cardiovascular disease. Clinical Chemistry. 55(2): 209-215.

18. Tanriverdi, H.; Tor, M.M.; Kart, L. Altın, R.; Atalay, F. and SumbSumbuloglu, V. (2015). Prognostic value of serum procalcitonin and C-reactive protein levels in critically ill patients who developed ventilator-associated pneumonia. Ann Thorac Med. 10:137-142.

19. Castell, J.V.; Gomez, L.M.J.; David, M.; Fabra, R.; Trullenque, R. and Heinrich, P.C. (1990). Acute-phase response of human hepatocytes: regulation of acute-phase protein synthesis by interleukin-6. Hepatology. (5): 1179-86.

20. Shima, M.; Nakao, K.; Kato, Y.; Nakata, K.; Ishii, N. and Nagataki, S. (1996). Comparative study of Creactive protein in chronic hepatitis $\mathrm{B}$ and chronic hepatitis C. Tohoku J Exp Med. 178: 287-297.

21. Blumberg, B.S. (1971). The Discovery of Australin Antigen and its Relation to Viral Hepatitis. VitroI. 7: 233. 
22. Norusis, M.J. (1986). Advanced Statistics .SPSS/PC. Chicagom ; SPSS Inc.

23. Stoica, G.; Angelescu, M.; Michiu, V.; Stoica, R.C. and Marta, R. (1979). Concentration of serum immunoglobulins in acute and chronic hepatic diseases. I. Serum-levels of $\mathrm{IgG}, \operatorname{Ig} \mathrm{A}, \operatorname{IgM}$ and $\operatorname{IgD}$ in young patients with viral hepatitis. Med Interne. 17(1) :35-47.

24. Bersohn, I.; Ipp, T.; Macnab, G.M.; Stevenson, C.M.; Miller, G.B. and Kew, M.C. (1975). Serum immunoglobulin levels in hepatitis-B antigen-positive and hepatitis-B antigen-negative acute hepatitis. $S$ Afr $J$ Med Sci. 40(1): 3-8.

25. Joshi, N.; Ayesha, Q. and Habibullah, C.M. (1990). Immunological studies in HBV-related chronic liver diseases. Indian J Pathol Microbiol. 33(4): 351354.

26. Bertoletti, A.; Adam, J. and Gehring, A.J. (2006).The immune response during hepatitis $\mathrm{B}$ virus infection. Journal of General Virology. 87: 14391449.
27. Guidotti, L.G. and Chisari, F.V. (1996). To kill or to cure: options in host defense against viral infection. Curr Opin Immunol. 8: 478-483.

28. Banchereau, J.; Briere, F.; Caux, C.; Davoust, J.; Lebecque, S.; Liu, Y.J.; Pulendran, B. and Palucka, K. (2000). Immunobiology of dendritic cells. Annu Rev Immunol. 18: 767-811.

29. Alberti, A.; Diana, S.; Sculard, G.H.; Eddleston, A.L. and Williams, R. (1978). Detection of a new antibody system reacting with Dane particles in hepatitis B virus infection. $\mathrm{Br}$ Med J. 2: 1056-1058.

30. Arai, J.; Ito, T.; Miyashita, Y.S.; Uchikoshi, M.; Morikawa, K.; Egughi, J.; Hayashi, E.; Nozawa, H. and Yohida, H. (2014). High level of Rheumatoid Factor is Associated with Hepatitis B Viremia I Patients with Chronic hepatitis B. Showa Univ Med Sci. 26(1): 75-83.

31. Dalkilic, E.; Oksuz, M.F.; Tufan, A.N.; Ozbek, A.; Nizamoglu, A.; Dolarslan, M.E.; Coskun, B.N. and Pehlivan, Y. (2015). Eur J Rheumatol. 2: 62-65.

32. Watanabe, K.; Ohkubo, Y.; Funahashi, Y.; Nishimaki, T.; Moritoh, T.; 
Kasukawa, R.; Kaise, S.; Tomita, T. and Matsukawa, A. (1991). An investigation on rheumatoid factor of different immunoglobulin classes in hepatitis B virus carriers. Clin Rheumatol.; 10: 31-7.

33. Singh, U.; Verma, P.K.; Bhagat, P.; Singh. S.; Singh, S. and Singh, N.K. (2012). IgG RF and anti-CCP2 antibody can be positive in undifferentiated arthritis due to streptococcal infection, hepatitis B virus, tuberculosis, trauma and hypothyroidism: a preliminary study. Rheumatol Int. 32: 2687-90.

34. Oliviero, B.; Cerino, A.; Varchetta, S.; Paudice, E.; Pai, S.; Ludovisi, S.; Zaramella, M.; Michelone, G.; Pugnale, P.; Negro, F.; Barnaba, V. and Mondelli, M.U. (2011). Enhanced Bcell differentiation and reduced proliferative capacity in chronic hepatitis $\mathrm{C}$ and chronic hepatitis $\mathrm{B}$ virus infections. J Hepatol. 55(1): 53-60.

35. Roosnek, E. and Lanzavecchia, A. (1991). Effec-tive and selective presentation of antigen-antibody complexes by rheumatoid factor B cells. J Exp Med. 175: 487-9.
36. Sutton, B.; Corper, A.; Bonagura, V. and Taussig, M. (2000). The structure and origin of rheumatoid factors. Immunol Today. 21: 177-83.

37. Ma, L.N.; LIu, X.Y.; Lu, Z.H.; Wu, L.G.; Tang, Y.Y.; Luo, X.; Hu, Y.C.; Yna, T.T.; Wang,Q.; Ding, X.C. and Xie, Y. (2017). Assessment of highsensitivity C-reactive protein tests for the diagnosis of hepatocellular carcinoma in patients with hepatitis Bassociated liver cirrhosis. Oncology Letters. 13: 3457-3464.

38. Liu, X.Y.; Ma, L.N.; Yan, T.T.; Lu, Z.H. Tang, Y.Y.; Luo, X. and Ding, X.C. (2016). Combined detection of liver stiffness and C-reactive protein in patients with hepatitis B virus-related liver cirrhosis, with and without hepatocellular carcinoma. Mol Clin Oncol. 4(4): 587-590.

39. He, X.; Wang, Y.; Zhang, W.; Li, H.; Luo, R.; Zhou, Y.; Liao, C.L.; Huang, H.; Lv, X.; Xie, Z. and He, M. (2014). Screening differential expression of serum proteins in AFP-negative HBV-related hepatocellular carcinoma using iTRAQ-MALDI-MS/MS. Neoplasma. 61: 17-26. 
40. Ma, L.N. Liu, X.Y. Luo, X. Hu, Y.C. Liu, S.W. Tang, Y.Y. Pan, J.L. and Ding, X.C. (2015). Serum highsensitivity C-reactive protein are associated with $\mathrm{HBV}$ replication, liver damage and fibrosis in patients with chronic hepatitis B. Hepatogastroenterology. 62(138): 36872.

41. Chisari, F.V. and Ferrari, C. (1995). Hepatitis B virus immunopathogenesis. Annu Rev Immunol. 13: 29-60.

42. Zhu, S.M.; Waili, Y.; XiaoTing, Q.; Chen, Y.M.; Lou, Y.F. and Chen, B. (2017). Serum C-reactive protein predicts early mortality in hospitalized patients with HBV-related decompensated cirrhosis. Medicine. 96(4): 1-4.

43. Xavier, P.; Belo, L.; Beires, J.; Rebelo, I.; Martinez-de-Oliveira, J.; Lunet, N. and Barros, H. (2006). Serum levels of VEGF and TNF-alpha and their association with $\mathrm{C}$-reactive protein in patients with endometriosis. Arch Gynecol Obstet. 273(4): 227-31. 